\title{
ANALYSIS OF TYPICAL LITHUANIAN FEATURES IN THE CONTEXT OF ACCESSION TO THE EUROPEAN UNION
}

\author{
Ligita Šimanskienè \\ Klaipeda University, H. Manto g. 84, LT-5800 Klaipeda, Lithuania \\ Received 20 November 2003; accepted 10 February 2004
}

\begin{abstract}
The work reviews the influence of cross-cultural features in management in the context of globalization. The work analyses the particular characteristics of a national stereotype of a Lithuanian based on the survey of other authors. Several hypotheses have been suggested based on SPSS programmer during the survey. The research has corroborated that the correct reasoning of typical characteristic features of a Lithuanian depends on age, position, sex, while the hypothesis 4 , asserting that the correct reasoning of typical characteristic features of a Lithuanian depends on education, hasn't been corroborated according to statistics and the variety of answers was due to different personal characteristics of respondents. Also the work analyses future forecasts for Lithuania in the European Union.
\end{abstract}

Keywords: Lithuanian features, accession countries.

\section{Introduction}

The globalization process taking place in the world with all their advantages and disadvantages determine sudden geopolitical, economical, technological and cultural changes, which inevitably affect European Union, the economical space of which Lithuania intends to integrate in, so at the same time they affect Lithuania as well. Similarly, the fall of the Berlin Wall, the democratic revolutions in central and Eastern Europe, and the collapse of the Soviet Union and its empire created a new strategic environment for Western Europe. The EU member states were immediately forced to address a series of interrelated security, political and economic issues, which had not been on the EU agenda. These included, how to incorporate a united Germany into western alliance, how to stabilize democracy and the free market in the new democracies in central and Eastern Europe, how to involve these states in a broader "European house" without antagonizing Russia, and how to tackle the potential large influx of economic migrants (Hix, 1999). How we see Lithuania and EU problems are on the one way the same on the other way- different.
Kvedaras, Ruskys, Umbrasas (2002) maintained, that the effect of common market, the payments from the EU budget, and the increase of foreign direct investments have the largest primary impact on Lithuanian economy. Of the integration to the EU the GDP of Lithuania during 2002-2009 period will be larger by 51,5 billion LTL, and especially the household consumption will increase. The average change in GDP that comes from the impact of integration will be about 10 percent of total GDP during the period of 2002-2009, and the growth rate of Lithuanian economy during the same period will be 0,6 percent higher compared with hypothetical nonintegration situation. The largest impact of integration would be incurred by industry sector, electricity, gas and water supply sector, and by wholesale and retail activities sector.

Lithuania has changed drastically since the restoration of state independence, but the world has also changed crucially. Creativity and knowledge have become powerful engines of socio- economic development. Although Lithuania has not reached the average EU indicators for the use of information technologies or 
contribution of knowledge intensive sectors to GDP, the growth in these fields is impressive (Rimkute, Voloschuk, 2003). Information technology brings together a wide range of different people who would otherwise never have met. However, like any other mean of communication, they introduce into human relationships. Management is the universal study of managing organizations with their important social and cultural environment, characteristic features of historically different national relationship between people. They influence the ways of managing organization, staff, and the general conduct of organizations. Frequent cases of mechanical adjustment of western business forms and methods in managing staff, paying no attention to important national Lithuanian values, personal characteristics is the cause of social conflicts and the performance doesn't correspond the desired level. It goes without saying that the processes of transformation in the society directed towards democracy and progress stimulate the application of modern management theories in managing organization. However, it is important to realize, that management is a multi-stage phenomenon and a complicated field of activity, closely related with the development of the society as well as its national culture. So in order to apply western theories of management in organizations in Lithuania it is necessary to find out whether Lithuanians have got essential cultural differences in comparison with other countries, which management theories we are going to adapt.

Researches of national characteristics have fatal influence in managerial culture, its efficiency and it is an important problem in management study, which hasn't yet been considered of great attention regarding its investigation.

The object of study - cultural differences with identification of typical national Lithuanian features.

The object of the article - to review research carried out by various management specialists who stress the importance cross-cultural features in management to find out respondents' attitude towards characteristic Lithuanian features.

Here are the following tasks in achieving the objective:

1. To demonstrate the influence of current globalization on national cultures.

2. To comment on the importance of this influence from the managerial point of view.

3. To identify typical national features of a Lithuanian.
4. To identify future forecasts for Lithuania in the European Union.

5. To prove the corroboration (rejection) of hypothesis.

The method - the analysis of scientific articles, comparison, the analysis of survey with the help of SPSS methodology, conclusions based on logics.

\section{Future forecasts for Lithuania in the European Union}

In 1997 Lithuania is not a very attractive country for foreign investors; therefore, we cannot expect an abrupt flow of investments. At the same time Lithuania is in a by far better position this respect than Latvia and Estonia. Many factors predetermining investments may be improved, therefore, Lithuania's attractiveness may be largely increased. This can be done by increasing the attractiveness of certain sites. It is also necessary to improve the advertisement of this country in the world (ed. Buracas, 1997). Central Europe is a region already well integrated with the EU in terms of trade (ed. Dawson, Fawn, 2002). It is becoming more strongly connected via investment, with a business culture fast approaching the diversity that can be found also in the West. But the legalicy of communism has left national economic structures with weaknesses that only time and investment can correct.

Legkauskas (2000) makes forecasts on the future of Lithuanians in the European Union. The EU declares solidarity of all cultures, equal opportunities for representatives of all cultures, promotes internal communication and co-operation. If this idyllic picture comes true, after fifty years the saying "I am Lithuanian" would have the same meaning for a speaker as today it has the saying "I was born in $\square$ ančiai", but this is not bad. Perhaps, the author specified rather too short period of time needed to assimilate us in the common mix of European nations. I would dare to state that this process will certainly take much more time, besides it is difficult to believe the aforementioned idyll will come true. Mayhew (2001) states that the problem of member countries how to assure the support of electorate and parliament in the case of delay during preparation for the accession, having no clear promises that such countries would join the union during the term of the most currently working parliaments.

Therefore it is highly important not only to prepare for the accession in Lithuania itself, but also to carry active work abroad promoting the advantages of the 
country. In further development of this topic we present some thoughts of Schultz (1998). The author noted that countries with high-income level while assisting countries with low-income level in increasing the efficiency of their economies make some serious mistakes. Firstly -investments to human capital are not given priority, i.e. there are no investments in the education on school and higher levels, in the health protection of society. People of low-income countries themselves give priority to the aforementioned issues in spite of their limited income. At present there is some emphasis on certain disputed issues in education system: too many specialist are prepared, too many certain professions are duplicated in a number of universities. Are these accusations reasonable? To my opinion, not. The more educated the nation, the better its economic achievements. Even if at present we cannot boost of high economic results, the more educated people we shall have, the higher probability that they would establish companies and create new jobs. The educated people are more flexible, they better understand the needs of organisation and as employees they mostly are initiative, seeking for knowledge and tolerant to diversities in opinions. By the way, instability and social conflicts in the society has caused the formation of new attitudes towards relationships among generations and towards the place of young people themselves in the social structure. ( $\square$ erpetis, 1997). When there are no conflicts in the development of society, the younger generation rather consistently and rhythmically intercepts the values, beliefs and stereotypes of the elder generation, i.e. respective level of mutual identification is achieved and sustained. However during the time of changes such inter-relation is broken.

That is why the questions arise. Will the young generation burdened by material deficiencies, facing the rapidly changing social roles be able to take the niche designed for it in the social structure? What will be the ideals and values of the contemporary generation entering the stage of independent life in the state and society of Lithuania, what prospects for selfrealization will the society create for the generation that is brought up in the dynamic and dramatic conditions of contradictive socialisation? I am convinced that it depends on the inter-relation between the individuality of the young generation itself and the maturity of social environment, which each time creates a unique social and historical situation. As Kazlauskiene (2001) notes there is fear that such phenomena as "brain leak" from the country will become a serious problem in the process of Lithuania's integration to the Western structures. If Lithuania becomes a member of the EU and Lithuania's citizens are granted the same rights of free employment in the EU member countries as the citizens of the EU, this would cause the vast wave of emigration of highly qualified (and not only) labour force from Lithuania. The number of emigrants will depend on the fact whether people perceive the signs of positive changes in economic-social situation of their country in the nearest future.

The management and implementation of projects in the European Union are decentralised and always aim at involving of different organisations and developing of civic society. Fontaine (1998) identifies the following major objectives of the European Union development:

- political dialog;

- free trade and freedom of movement;

- economic co-operation;

- financial co-operation;

- cultural co-operation;

Kolonaitis (2001) states that candidate countries are considered as serious partners of the EU both in economic and political relations. Junevičius (1999) emphasises that the accession to the EU is necessary as the following main directions of the common foreign policy of the EU can be defined: the policy in regard of Russia; the Middle and Eastern European policy; the common policy in regard of the third countries; the common trans-Atlantic policy. Vareikis (2002 a) also considers the necessity of Lithuania's accession. He states, that Lithuania must strengthen power in order to formulate the interests of the $21^{\text {st }}$ century. The interests will be necessary if we want not only to have our voice formally but to use it as well. Globalisation (best of all under the management of Europeans) would be the best of all ways for such Lithuania if it joins the union where nobody would pay attention nor to small-scale egoism nor to nervousness, nor to some mistakes in the strategic plan. The author states that the accession has bigger emotional -political rather than economic importance. Vareikis (2002 b) comments the question "why do we need to join the EU?", stating that there are several myths without any real ground, namely: 1) myth about loosing of national identity and sovereignty; 2) myth that Russia would buy out Lithuania; 3) myth that Europe would tell us what to do and is going to hurt us; 4) myth that only politicians and bureaucrats of economically strong countries need the European Union. To my opinion, all these myths, indeed, are only myths. Probably, these fears have arisen because of one of the most typical features of a Lithuanian mistrusting others - the feature based on the experience of the former occupation. 
What features do Lithuanian people lack? Those who are in favour of accession to the EU specified a bit different features than those who doubt or are against the accession. The repeating thought that the traditional mentality should be changed, that somebody should take care of all citizens but nobody tries to take initiative. It is stated that there is a lack of activeness (both in the politics and in business stratum), optimism, patience, resolution, self-reliance, ability to organise, enthusiasm, one should not dwell on the past but to look for the future, to get rid of conservativeness, to be not afraid of changes, swiftness, to strive for innovations, to be not afraid of expressing one's opinion, to care not only of personal interests, there is a lack of sense of respect (especially in regard of our own nationals), flexibility, self-respect, openness, trusting others, to stop envying each other, there is a lack of patriotism, broader thinking, responsibility, diligence (not only talks), ability to innovate, need for learning, communication skills (team sense), morality, ability to adapt, good will, to get rid of fear of foreigners. There are also few very pessimistic responses: nothing should be done as nothing depends on us; do not dance under others' music (a lack of self-respect); common people would have no benefits whatsoever; if there is wealth, all problems would disappear by themselves; do not wait for anything good; to escape abroad because everybody only mocks and there are no jobs. Probably, these respondents could be answered with the answers of other respondents identifying what features Lithuanians lack. Concluding, the most lacked features are: optimism, reliance on one's own strength, at last the understanding that only you are responsible for your both material and mental wealth, and that the wealth by itself is not neither good nor evil.

\section{Management Problems of Organizations in the Context of Globalization}

Bauman (2002) asserts that in fact processes of globalization cause lots of problems: in the world where capital has lost its permanent abode and national governments have nearly lost control over financial flood, the greater leverage of economic policy isn't functioning any more. The image of global confusion most probably reflects new understanding (it has lost its complicity but that wasn't necessarily determined by the sudden end of blocks policy) that things which seemed to be under firm control or at least "technical control", in fact are spontaneous and accidental. The author gives the following definition of the globalization idea; the world matters are indeterminate, without control and laissez-faire. Cultural-historical peculiarities, two different cultural opinions based on historical formulation form the basis to assimilate and adapt both Western and Eastern ideas and values, thus becoming the "intermediary" between the East and the West. Kazlauskas (1993) emphasized that the nation's political state and development perspectives are determined by outside and inside factors. The first belong to the entire complex of international relations based on treaties (co-ordinate) or compulsion (subordinate) bonds. The form of the second group factors consists of free inward decision of every nation to choose the most acceptable form of political regime. Held, McGrew, Goldblatt, Perraton (2002) introduced three types of arguments for a largescale discussion about the foundation and importance of cultural globalization. Hyper- globalists describe or predict homogenization based on popular American culture. Others support those remaining sceptical and emphasizing the instability of global culture and compare it with national cultures having firm, even increasing geopolitical contradictions in cultural differences of the main world civilization. Those who support transform-nationalistic position describe the mixture and nations as the phenomenon which forms cultural hybrids and the new nets of global cultures. Tomlinson (2002) emphasizes that in the global world national cultural identities remain resistant and important. The author states that the remains of national obstacles for global cosmopolitan identities to arise even because those identities fully occupy people's cultural imagination and broaden outlook. At the same time the author emphasizes that perhaps globalization won't create entire global culture according to a certain, historically unique model of national cultures. However, having accepted this as a distinctive feature, it might turn out that there are means of estimation of global cultural identity. Melnikas (2002) says that "conversion" of global spaces into new qualitative states found in these spaces and processes have the tendency to acquire new qualities appearing on the new scale due to their characteristic changes. Processes of this kind also predetermine formulation of new forms of such spaces and processes which means that these spaces and processes in certain periods of development or certain stages of development might transform into new spaces and new processes.

Šimanskienè (2002a), Šimanskienè, Venckutè, Župerkienè (2003) turned their attention to the fact that managers should know their subordinates well and especially pay attention to their nationalities. In their opinion, representatives of every nation have certain 
features of their character, and only being aware of them, it is possible to effectively motivate an employee. In order to manage the organization successfully, it is necessary to form and cherish the organization culture. Lewies (1999), Jung and Avolio (1999) made investigations in the influence of management styles in group performance. The results proved that the same style of management might be realized in different ways which make a different effect on motivation and activity of individuals who represent various cultural groups. $\square$ ukauskas (2000), who studied the ideas of various authors about possibilities of penetrating into different markets, states that the means of actions which might seem effective in one country might appear ineffective in another. The arguments are convinced by differences which lie in cultural and living standards of certain countries. Zakarevičius (1998) also emphasized that little attention is being paid to investigations of natural features. It is necessary to prepare suggestions, recommendations, methodology, with the help of which it might be possible to change, improve the cosmopolitan management system in the way possible to make positive evaluation and eliminate negative national features. Shane, Venkataraman, MacMillan (1999) defined that national culture has the direct influence towards organizations cultures as well. They asserted that international corporations have more chances to compete than home organizations because they operate in the diverse environment which makes them look for means insuring competition. They also emphasized that it is not permitted to export strategies of one country into another without having checked if they fit that national environment. This fact has to be taken into consideration; otherwise the attempts might become ineffective. Therefore it is important to realize the existing differences and to use them in business development. Hofstede (1992) who investigated organizations cultures formulated four main models of values: the distance authority, attempts to avoid in determination, individualism and collectivism, manhood and womanhood. The author proved that organization cultures together with national and ethical factors are related. He makes a detailed analysis of the typology of organizations cultures on the basis of the national-state characteristics. The background of the typologies is made of valuable orientations and faith which are characteristic to certain national-state units and ethnic groups. It has the direct relations with the religion existing in that society. Palich, Hom, Griffeth (1995) asserted that the famous Japanese productivity comes from the experience of Japanese enterprises, maximizing the loyalty to their company. The results of the research stimulated international investigation in the field of identity. In order to achieve loyalty to their motherland, some famous companies praise the company's values with the aim to remind the employees of their organization's citizenship. It has been proved by the research that the usual culture of partnership doesn't alone restrict and destroy various national cultural identities which exist in multinational companies. Fladmoe - Lindquist, Jacque (1995) say that in order to develop trade and services in other cultures, firstly it is necessary to be aware of differences which exist among foreign customers and be able to co-operate with employees in overseas subsidiaries, having in mind that the ethics of their work exists in different language, mentality, and cultural traditions. It has also been found out that the greater the cultural distance between the headquarters and the newly established subsidiary in another country is, the greater is the uncertainty in relations with overseas employees. Park, Ungson (1997) investigated the loyalty of members of international organizations. The most popular explanation says that international companies are less stable and the employees are less loyal than of those working for national companies. However, the research carried out by authors couldn't prove it. On the contrary, due to cultural differences these companies used to work more efficiently because the best features of cultural differences had taken over. The employees were stimulated mostly by economic motivation, common actions and close relationship.

According to Ulčinskaitè (2000) the social consequences caused by the process of globalization might be estimated in three ways. Firstly, increasing employment due to abundance of general working power. Because of increasing working power in well developed countries, the general number of vacancies, working hours and employees having full-time jobs is constantly going down. Secondly, the constantly growing scale of deformation of economic activity due to general integration of finance, economics and culture as well as the rising international working power mobility: more people have temporary, forbidden jobs and avoid paying taxes. Thirdly, because of the importance of increasing global problems in controlling inside matters, tendencies ought to be taken into consideration from outside, which cause a gap between inner demands spoken up by the society and the government which finds it necessary to combine it with the requirements from outside. Lekavičienè (2000) states that different cultures create different situations for individuals and take them into systems of different pressure. Culture 
also brings difference into subjective interpretation of reality. It is said that the objective of cross-cultural research shouldn't the attempt to explain the phenomenon of culture but it should prove that culture influences the behaviors and the way of thinking of an individual. Mockaitis' (2002) research proved that culture not only makes influence on the views about management, but this influence is of great importance. It has become evident that it is possible to foresee the views of the members of the organization by comparing relative positions of countries according to their cultural dimensions and by controlling the influence of demographic differences made on results. Liubiniene (2002) according to Berger singles out four features of modernization: 1. Disappearance of small, traditional communities. 2. Appearance of possibilities for personal choice. Due the influence of traditions, people are becoming unrestricted. 3. Variety of faiths. 4. Thoughts about future.

\section{The Analysis of Lithuanian Cultural Differences}

As we endeavor to identify the character of the Lithuanian nation through customs and traditions, perception and view of the world, we come to understand what it meant to be Lithuanian. By adopting and preserving the basic cultural traits of the Lithuanian nation we can remain Lithuanian even while residing far from Lithuania, our country of origin. But the most important national mark of a Lithuanian does not simply know Lithuanian customs and traditions (through this helps to remain close to one's origins). A Lithuanian's most vital national trait is the Lithuanian language. Smith (1995) singles out two meanings of "nation": nation as a "natural" historical unit and nation as a concrete political objective or ideal. In fact ethnic nation is an old historical and cultural derivative often religious in its origin and always closely linked with the rhythm of "nature". It evokes the feeling of collective ethnocentrism: attachment to one's ethnic-genetic community, settled in its area. The other is of a modern, revolutionary and unique rationalistic concept - a political ideal characteristic to the century of enormous changes. Thus the national feeling becomes ideology competing with other ideologies and being different due to its strong relationship with its "inborn" collective emotion which has always enriched ethnic association. Only mature national culture corresponding the requirements of present civilization can deal with social pressures.Lithuanian countryside and climate also influence personality and character of a Lithuanian (Šimanskienè, 2002b). Slow temper, melancholia might be explained by the lack of the sunlight. Short period of vegetation forces a farmer to stay at home, dream and trust the destiny. Lithuanians don't belong to the nation of sailors nevertheless, they live by the sea. Sad and nostalgic songs are common to lowlanders. Lithuanian nation developed as the nation of woods and forests. Lithuanian countryside brings the feeling of lyrics; the nature awakes feelings, not thoughts. Lithuanian lack of enthusiasm, laziness might be explained as a peculiar relation with nature, climate, the stereotype formed by the landscape which provides with characteristic features of dreaminess, lyricism, sadness. Račiūnaitė (2002) discovered that the autonomy in rural community was not of great importance. There prevailed the dominant opinion in the nation's consciousnesses that only those are happy and successful who keep to the customs of their ancestors. In the centre of the village community there is the family and the characteristic restraint seeking for material wealth not for oneself, but to help others. They were one of the most distinct cultural features developed in the family of a traditional rural community. According to Juknevičius (2002) research these are already altered values, because only $29 \%$ of respondents in 1999 said that public work brings benefit in comparison to $47 \%$ of respondents in 1990. Mitrikas and others (1999) notes that the Western ideology pays greater attention to one's personal needs-health, creative work, travels and money and the values of the state, nation and family have been losing their importance. While the highest values in the world outlook of Lithuanians are: family, wealth, money, moral virtues, wisdom, belief in God, nation; and the least important are: the state, travels, friends. According to Ulčinskaite and others (2000) Lithuanian people lack the following features: selfindependence, honesty, the sense of responsibility, ability to socialize, efficiency, ability to form a team and manage it, initiative, ability to gather and facts and make analysis, ability to co-ordinate performance. Lewis (2002) says, that Lithuanians have the following specific features like hospitality, family, honesty, love of nature, saving national identity, romanticism. Mockaitis (2002) stressed that Lithuanians lack initiative, wait for the manager to decide when their activity is necessary. Šalčiuvienè, Auruškevičienè (2002) revealed ten the most important cultural values characteristic to all ethnic groups in Lithuania: family orientation, social recognition, risk, power and wealth, freedom, physical and financial security, job, health, true friendship, flexibility. Juknevičius' (2002) investigations revealed attitude towards competition: competition is positive as it stimulates people to work 
better and search for new ideas. 56\% of respondents approve of the idea, though the numbers of approving respondents have diminished in comparison to $73 \%$ of respondents in 1990.This shows that people still are afraid of taking responsibility for their lives and prefer waiting for the help from the government as if the statesmen can and must be responsible for everyone's material welfare. According to the results of the research payment is the most valued at work in contrast to responsibility which is the least valued among Lithuanian people. In author's opinion our working conscientiousness in fact is of the same level like farmers and handicraftsmen. Šimanskienè's (2002a) research demonstrated that responsibility is one of the most typical features of a Lithuanian. Why are the results of research different? It might be explained by having asked respondents different questions with different formulation of questions. However, the lack of initiative is demonstrated by all results of research.

It is rather complicated to compare the data because of different methods and methodology used; respondents were given different lists of values which are partly similar and it rather complicated to make detailed comparison, nevertheless the general values are nearly the same.

Several hypotheses have been suggested:

Hypothesis 1: the judgment of typical Lithuanian features is based on age;

Hypothesis 2: the judgment of typical Lithuanian features is based on the position;

Hypothesis 3: the judgment of typical Lithuanian features is based on the sex;

Hypothesis 4: the judgment of typical Lithuanian features is based on education.

\section{The Research on Typical Lithuanian Features of Character}

For carrying out the research, the questionnaire was prepared with the list of typical features according to the ones singled out by other authors. The respondents were asked to rate them according to the rate of importance where 7 points went to the most typical feature while 1 point - to the least typical one. In the formation of questions both positive and negative alternatives for the answers were given. While planning the research it is necessary to choose the minimum number in order to make statistically trustful conclusions. Selective methods are based on the theory of chances, though in selection it is impossible to avoid mistakes, unless all the population took part in the research. In scientific research 95\% is trustworthy (Kardelis, 1997). In order to get the false answer of $5 \%$ it is necessary to inquire 400 respondents from 5,000 people. Such numbers are provided by Ch.Nachmias, D.Nachmias (1985). They note that it is enough to inquire 385 respondents from 10,000 employees to get $5 \%$ of false answers. So we have inquired 1050 respondents and we might state that it is the right number to get reliable answers ( out of general number of population of $3,490,800$ according to the data of 2001). The data of the questionnaire was processed by SPSS (Special Package for Social Science) program with the onefactorial dispersal analysis (ANOVA) because variables are measured by the rating scale.

1050 respondents filled in the questionnaire: 396 men and 654 women of different age, background and position. I3 respondents - with unfinished secondary education, 121 - with the secondary education, 88 secondary education and profession, 312 - higher education, 486 - with university diploma and 30 students. According to age: 39 - under 20;343 - from 21 to $30 ; 353$ - from 31 to $40 ; 209$ - from 41 to 50 ; 90 - from 51 to 60 ; and 16 older than 61.According to the position at work: 72 - top managers,; 157 middle managers, 103 - lower rank managers; 508 professional workers; 83 technicians, 83-workers, 39 - unqualified workers.

The general opinion about typical Lithuanian features is described in table 1 and diagram 1 ( 1 - least important features, 7 - very important features).

There is no great difference among average points in assessment. The respondents mentioned the dominating features of jealousy $(5,8)$, diligence $(5,7)$, hospitability $(5,7)$. Showing initiative $(3,8)$ and trust in other $(3,9)$ seem to be least important.

In order to show the difference in the analysis and different outlook to the same features regarding respondents' position at work, age difference, education and sex, one-factorial dispersal analysis (ANOVA) was made with the help of SPSS, which allows to judge how the general results of 20 features included in the questionnaire differ among the different layers of population (different position, age, education and sex). ANOVA is being often applied in cases when variables are measured according to the rating scale. It is important that the arithmetical mean were sensible.

According to ANOVA method, the results comparing the average arithmetical mean of features, depends on position. As already mentioned, approval or disapp- 
Table 1. The general opinion about typical Lithuanian features

\begin{tabular}{|c|c|c|c|c|c|c|c|}
\hline \multirow{2}{*}{ Features } & \multicolumn{7}{|c|}{ Assessment } \\
\hline & 1 & 2 & 3 & 4 & 5 & 6 & 7 \\
\hline Showing initiative & $5,6 \%$ & $8,6 \%$ & $27,4 \%$ & $30,4 \%$ & $16,3 \%$ & $6,5 \%$ & $5,2 \%$ \\
\hline Honesty & $4,9 \%$ & $10,7 \%$ & $17,9 \%$ & $27,9 \%$ & $21,1 \%$ & $9,3 \%$ & $8,2 \%$ \\
\hline Fairness & $4,3 \%$ & $9,2 \%$ & $17,6 \%$ & $28,9 \%$ & $21,0 \%$ & $11,3 \%$ & $7,7 \%$ \\
\hline Responsibility & $1,8 \%$ & $5,0 \%$ & $13,7 \%$ & $25,7 \%$ & $27,2 \%$ & $16, \%$ & $9,9 \%$ \\
\hline Trust in others & $7,8 \%$ & $11,7 \%$ & $22,8 \%$ & $23,9 \%$ & $17,9 \%$ & $11,0 \%$ & $4,9 \%$ \\
\hline Diligence & $0,6 \%$ & $1,4 \%$ & $2,7 \%$ & $9,0 \%$ & $20,9 \%$ & $35,2 \%$ & $30,2 \%$ \\
\hline Hospitality & $1,2 \%$ & $2,2 \%$ & $3,7 \%$ & $10,3 \%$ & $19,7 \%$ & $27,0 \%$ & $35,9 \%$ \\
\hline Modesty & $3,1 \%$ & $4,5 \%$ & $11,3 \%$ & $23,0 \%$ & $22,6 \%$ & $20,7 \%$ & $14,8 \%$ \\
\hline Love of motherland & $4,8 \%$ & $5,8 \%$ & $11,2 \%$ & $24,0 \%$ & $22,1 \%$ & $19,6 \%$ & $12,5 \%$ \\
\hline Restraint & $2,5 \%$ & $4,2 \%$ & $12,3 \%$ & $23,4 \%$ & $24,2 \%$ & $21,7 \%$ & $11,7 \%$ \\
\hline Individualism & $3,4 \%$ & $8,5 \%$ & $17,9 \%$ & $24,4 \%$ & $21,6 \%$ & $17,0 \%$ & $7,2 \%$ \\
\hline Independence & $2,6 \%$ & $3,9 \%$ & $15,7 \%$ & $24,6 \%$ & $26,0 \%$ & $17,6 \%$ & $9,6 \%$ \\
\hline Lack of enthusiasm & $5,7 \%$ & $7,4 \%$ & $17,3 \%$ & $29,4 \%$ & $17,4 \%$ & $16,0 \%$ & $6,8 \%$ \\
\hline Obedience & $2,1 \%$ & $4,8 \%$ & $9,0 \%$ & $20,0 \%$ & $25,5 \%$ & $25,1 \%$ & $13,5 \%$ \\
\hline Conservatism & $2,2 \%$ & $3,3 \%$ & $9,2 \%$ & $18,9 \%$ & $21,2 \%$ & $26,4 \%$ & $18,8 \%$ \\
\hline Jealousy & $3,9 \%$ & $2,3 \%$ & $2,4 \%$ & $7,6 \%$ & $15,1 \%$ & $26,9 \%$ & $418 \%$ \\
\hline Selfishness & $4,3 \%$ & $3,0 \%$ & $6,5 \%$ & $16,6 \%$ & $25,3 \%$ & $23,8 \%$ & $20,5 \%$ \\
\hline Admiration for strangers & $6,8 \%$ & $7,1 \%$ & $11,8 \%$ & $19,4 \%$ & $20,8 \%$ & $20,9 \%$ & $13,2 \%$ \\
\hline Punctuality & $1,9 \%$ & $3,4 \%$ & $9,7 \%$ & $25,4 \%$ & $30,8 \%$ & $19,0 \%$ & $9,8 \%$ \\
\hline Sense of humor & $3,1 \%$ & $4,6 \%$ & $12,3 \%$ & $24,4 \%$ & $25,9 \%$ & $17,8 \%$ & $11,9 \%$ \\
\hline
\end{tabular}

roval of the hypothesis might be judged by $\mathrm{p}$ meaning. The average of importance was defined by 0,05 , so we might say that showing initiative is statistically important $(p=0,025)$; love of motherland $(p=0,019)$; conservatism $(p=0,014)$, jealousy $(p=0,033$; selfishness $(p=0,005)$; admiration for strangers $(p=$ 0,010).Unfortunately, the results of the test don' provide with the answer in which groups the average answers to the questionnaire differ. For this reason the criteria Post hoc is used. They might be calculated with the help of SPSS and the result of making decision is calculated through $\mathrm{p}$. So with the help of criteria Post hoc we will give the answer to the question how position influence the choice of answers concerning the typical Lithuanian features. In statistical assessment the difference is essential: showing initiative- among top managers and professionals; middle managers and specialists and specialists and technicians. Love of motherland among top managers and workers and unqualified workers, specialists; middle managers and unqualified workers; specialists and workers and unqualified workers and technicians and unqualified workers. As one can see these features have quite different assessment. Conservatism - among all managers, specialists and technicians and workers as well as unqualified workers. Selfishness - among top managers and all the other type of employees as well as unqualified workers and middle managers and specialists. Admiration for strangers - among workers and all types of managers and specialists. In conclusion it might be said that assessment depends on position.

There is different assessment of initiative, honesty, diligence, modesty, love of motherland, restraint, individualism, obedience conservatism, jealousy and sense of humor in different age groups. Post hoc criteria helps to define in which age groups these differences are evident. The assessment of showing initiative differs in 2 and 5, 3 and 5 groups ( here : 1 a.gr.-under 20, 2a.gr. 21- 30, 3a.gr.- 31-40, 4a.gr. 4150, 5a.gr. 51-60, 6a.gr. over 60). The assessment of honesty differs in 1 and 2, 2 and 3, 3 and 4 groups. Diligence acquires different assessment in the group of young people, i.e. group 1 and also 2 and 3 . Modesty is also assessed differently from groups 2, 3 , and 4 by group 1 . Different opinions were found 
in assessing love of motherland in groups 1,2 and the rest. The same tendency prevails in answers to other questions: in all the following answers there is the difference among respondents in groups 1,2 and others. Education was of no significant importance in answering questions according to the analysis because $90-93 \%$ of different answers were related to personal qualities of respondents. And the last factor which interests us is the sex, the importance of which might be judged from ANOVA. From the analysis we can see that showing initiative is different (male $-4,1$, female $-4,9$ ), love of motherland( male $-4,5$, female - 4,7), restraint (male 4,5, female - 4,9), obedience (male $-4,8$, female $-4,40$, trust in others (male $-4,1$, female $-3,8)$. But the difference in results of this factor is also little.

We discussed the influence of each factor separately, though it is possible that the outlook to the above discussed features might be determined by the influence of these factors too, so it is wise to think that all these factors are related with each other, i.e., depend on each other. We can judge about this type of relationship from rating correlation coefficients by Spearman, the meanings of which are given in table 2 . Dependence among factors is statistically significant if the leveler of significance is less than 0,05 and the influence is greater due to the coefficient closer to 1 (positive attachment) or -1 (negative attachment). In the table the upper number shows the meaning of correlation coefficient, the lower - the level of importance. So we can see that nearly all the factors influence each other, and among position and education there exists statically significant negative relation $(\mathrm{r}=0,238$ and $\mathrm{p}=0,000)$, Negative among position and age $(r=-0,143$ and $p=0,000)$ which means that those with higher position are older people with higher education. There is statistically important relation between posts and sex $(r=-0,094$ and $\mathrm{p}=$ $0,003)$ which means that men have higher positions. Education depends on age $(\mathrm{r}=-0,2093$ and $\mathrm{p}=$ 0,003 ), i.e., older people have higher education.

We can make an assumption that the aforementioned answers are influenced by the same 4 factors, the existence and strength of the impact as well as relations among the answers themselves are shown in table 2, i.e. we again will make conclusions on dependency using Spearman's rank correlation coefficient. Those who deepen knowledge like competing, they think that Lithuania does not need examples of other countries and that informal communication is not a necessary feature of leaders - to this group belong persons who have already acquired education, who work in lower positions and younger people. Those who value traditions prefer working in groups, are proud of their country, do not see any problems in working with foreigners and are of elder age. Those who like working in groups are more punctual, expect informal communication with leaders, are proud of their country and like working with foreigners. Those who are in lower positions are more punctual. Those who are in higher positions, have better education and younger persons more like competing; also men more value competition. Those who like informal communicating with leaders love their country, do not see any problems in working with foreigners. Those who are proud of their country think that Lithuania needs other country's example (mostly mentioned Scandinavia, especially Sweden, also Ireland) and are more willing to work with people of other nationalities. Men more tend to think that Lithuania needs other country's example. There are more young people working in multi-national collectives and they have no communication problems. Younger men more tend to answer that there are no communication problems. All this interpretation can be presented from the other side (e.g. those who are not engaged in additional learning do not consider competition as positive, they more prefer informal communication of leaders, etc.).

After the analysis we might make conclusions and find out if hypotheses were corroborated. Hypothesis 1 has proved that judgment about typical Lithuanian features depends on age as in all cases the outlook of older and younger respondents differs. Hypothesis 2 has proved statistically with the help of Post hoc that judgment about typical Lithuanian features depends on position. Hypothesis 3 also proved that judgment about typical Lithuanian features depends on sex, but differences are very insignificant. Hypothesis 4 hasn't statistically proved that that judgment about typical Lithuanian features depends on education because the variety of answer were influenced by personal qualities of the respondents.

\section{Conclusions}

1. So in order to apply western theories of management in organizations in Lithuania it is necessary to find out whether Lithuanians have got essential cultural differences in comparison with other countries, which management theories we are going to adapt.

2. Hypothesis 1 has proved that judgment about typical Lithuanian features depends on age as in all cases the outlook of older and younger respondents differs. Hypothesis 2 has proved statistically with the help of 
Table 2. Correlation table of typical features of Lithuanian

\begin{tabular}{|c|c|c|c|c|c|c|c|c|c|c|c|c|c|c|}
\hline & $\begin{array}{c}\text { Know- } \\
\text { ledges } \\
\text { impro- } \\
\text { ving } \\
\text { skills }\end{array}$ & Values & $\begin{array}{c}\text { Cha- } \\
\text { racter } \\
\text { of work }\end{array}$ & $\begin{array}{l}\text { Punc- } \\
\text { tuality }\end{array}$ & $\begin{array}{c}\text { Com- } \\
\text { petition }\end{array}$ & $\begin{array}{l}\text { Rela- } \\
\text { tion- } \\
\text { ship }\end{array}$ & $\begin{array}{c}\text { Point } \\
\text { of view } \\
\text { to } \\
\text { country }\end{array}$ & $\begin{array}{l}\text { Exam- } \\
\text { ple of } \\
\text { country }\end{array}$ & $\begin{array}{c}\text { Collec- } \\
\text { tive }\end{array}$ & $\begin{array}{l}\text { Com- } \\
\text { muni- } \\
\text { cation }\end{array}$ & Duties & $\begin{array}{l}\text { Educa- } \\
\text { tion }\end{array}$ & Age & Sex \\
\hline \multirow{2}{*}{$\begin{array}{l}\text { Know- } \\
\text { ledges } \\
\text { impro- } \\
\text { ving } \\
\text { skills } \\
\end{array}$} & & $-0,044$ & 0,000 & 0,035 & $-0,160$ & 0,069 & $-0,042$ & $-0,064$ & 0,014 & 0,022 & $-0,101$ & 0,074 & $-0,206$ & $-0,045$ \\
\hline & & 0,167 & 0,989 & 0,263 & 0,000 & 0,028 & 0,183 & 0,042 & 0,657 & 0,497 & 0,001 & 0,019 & 0,000 & 0,151 \\
\hline \multirow[t]{2}{*}{ Values } & & & 0,181 & $-0,003$ & $-0,067$ & 0,077 & 0,063 & $-0,049$ & 0,046 & 0,072 & $-0,022$ & 0,038 & $-0,079$ & $-0,015$ \\
\hline & & & 0,000 & 0,913 & 0,035 & 0,015 & 0,046 & 0,124 & 0,142 & 0,022 & 0,495 & 0,230 & 0,012 & 0,636 \\
\hline \multirow{2}{*}{\begin{tabular}{|l|l}
$\begin{array}{l}\text { Charac- } \\
\text { ter of } \\
\text { work }\end{array}$ \\
\end{tabular}} & & & & 0,077 & 0,026 & 0,099 & 0,095 & $-0,020$ & 0,017 & 0,071 & 0,030 & 0,059 & $-0,003$ & 0,021 \\
\hline & & & & 0,015 & 0,417 & 0,002 & 0,003 & 0,533 & 0,599 & 0,025 & 0,337 & 0,060 & 0,915 & 0,512 \\
\hline \multirow[t]{2}{*}{$\begin{array}{l}\text { Punc- } \\
\text { tuality }\end{array}$} & & & & & 0,051 & $-0,001$ & 0,075 & 0,009 & 0,018 & $-0,019$ & $-0,099$ & 0,011 & $-0,026$ & 0,023 \\
\hline & & & & & 0,110 & 0,986 & 0,017 & 0,785 & 0,576 & 0,557 & 0,002 & 0,720 & 0,411 & 0,472 \\
\hline \multirow[t]{2}{*}{$\begin{array}{l}\text { Compe- } \\
\text { tition }\end{array}$} & & & & & & 0,001 & 0,058 & $-0,015$ & $-0,043$ & 0,000 & 0,096 & $-0,070$ & 0,159 & 0,150 \\
\hline & & & & & & 0,967 & 0,068 & 0,644 & 0,170 & 0,991 & 0,002 & 0,028 & 0,000 & 0,000 \\
\hline \multirow[t]{2}{*}{$\begin{array}{l}\text { Rela- } \\
\text { tionship }\end{array}$} & & & & & & & 0,111 & $-0,043$ & $-0,054$ & 0,082 & $-0,034$ & 0,017 & $-0,054$ & 0,093 \\
\hline & & & & & & & 0,000 & 0,172 & 0,090 & 0,010 & 0,287 & 0,595 & 0,087 & 0,003 \\
\hline \multirow[t]{2}{*}{\begin{tabular}{|l}
$\begin{array}{l}\text { Point of } \\
\text { view to } \\
\text { country }\end{array}$ \\
\end{tabular}} & & & & & & & & $-0,100$ & 0,000 & 0,083 & 0,013 & $-0,061$ & $-0,040$ & 0,046 \\
\hline & & & & & & & & 0,002 & 0,989 & 0,008 & 0,675 & 0,056 & 0,206 & 0,145 \\
\hline \multirow[t]{2}{*}{\begin{tabular}{|l|}
$\begin{array}{l}\text { Exam- } \\
\text { ple of } \\
\text { country }\end{array}$ \\
\end{tabular}} & & & & & & & & & $-0,040$ & $-0,042$ & $-0,031$ & $-0,010$ & 0,024 & $-0,124$ \\
\hline & & & & & & & & & 0,207 & 0,182 & 0,331 & 0,753 & 0,449 & 0,000 \\
\hline \multirow[t]{2}{*}{$\begin{array}{l}\text { Collec- } \\
\text { tive }\end{array}$} & & & & & & & & & & $-0,145$ & $-0,008$ & $-0,005$ & 0,099 & $-0,029$ \\
\hline & & & & & & & & & & 0,000 & 0,793 & 0,870 & 0,002 & 0,352 \\
\hline \multirow[t]{2}{*}{$\begin{array}{l}\text { Com- } \\
\text { munica- } \\
\text { tion }\end{array}$} & & & & & & & & & & & $-0,033$ & $-0,019$ & 0,094 & 0,064 \\
\hline & & & & & & & & & & & 0,299 & 0,546 & 0,003 & 0,042 \\
\hline \multirow[t]{2}{*}{ Duties } & & & & & & & & & & & & $-0,283$ & $-0,143$ & 0,094 \\
\hline & & & & & & & & & & & & 0,000 & 0,000 & 0,003 \\
\hline \multirow[t]{2}{*}{\begin{tabular}{|l}
$\begin{array}{l}\text { Educa- } \\
\text { tion }\end{array}$ \\
\end{tabular}} & & & & & & & & & & & & & 0,093 & $-0,005$ \\
\hline & & & & & & & & & & & & & 0,003 & 0,866 \\
\hline \multirow[t]{2}{*}{ Age } & & & & & & & & & & & & & & 0,092 \\
\hline & & & & & & & & & & & & & & 0,004 \\
\hline
\end{tabular}


Table 3. Rating correlation coefficients by Spearman

\begin{tabular}{|l|c|c|c|c|}
\hline & Position & Education & Age & Sex \\
\hline Position & 1,000 & $-0,283$ & $-0,143$ & 0,094 \\
\hline & & 0,000 & 0,000 & 0,003 \\
\hline Education & & 1,000 & 0,093 & $-0,005$ \\
\hline & & & 0,003 & 0,866 \\
\hline Age & & & 1,000 & 0,092 \\
\hline & & & & 0,004 \\
\hline Sex & & & & 1,000 \\
\hline
\end{tabular}

Post hoc that judgment about typical Lithuanian features depends on position. Hypothesis 3 also proved that judgment about typical Lithuanian features depends on sex, but differences are very insignificant. Hypothesis 4 hasn't statistically proved that that judgment about typical Lithuanian features depends on education because the variety of answer were influenced by personal qualities of the respondents.

3. We can see that nearly all the factors influence each other, and among position and education there exists statically significant which means, that those with higher position are older people with higher education. There is statistically important relation between posts and sex which means, that men have higher positions. Education depends on age, i.e., older people have higher education.

4. The results of the opinion pools carried out in the course of research have shown that the major part of respondents are in favour of Lithuania's accession to the EU. However there is a small part of respondents who are doubting or against the accession to the EU and they give the following arguments: rules imposed by bureaucrats from Brussels; we are not needed there; nobody waits for us; we are useful only as a new market; too high, sometimes even unrealistic requirements, e.g. closure of Ignalina Nuclear Power Plant, are demanded; Lithuania has not been prepared for the different changes and still needs more time to prepare; after a decade since accession Lithuania ceases to exist, we shall live as in a slavery. Those who are in favour of the accession give the following reasons that to their opinion have benefits for Lithuania: the economic situation of the country will improve as producers will be able to sell freely their production in other countries; more jobs will be created because of more foreign investors; opportunity of legal work in other countries; ensured security of the country; having joined the forces we are useful for all countries; more serious attitude towards Lithuania (as a "successful" country).

\section{References}

1. Bauman, Z. Globalizacija. Vilnius: Strofa, 2002.

2. ed. Buracas, A. Lithuanian Economic Reforms: Practice and Perspectives. Vilnius: Margi rastai, 1997.

3. ed. Dawson, A. H., Fawn, R. The Changing Geopolitics of Eastern Europe. London: Frank CASS, 2002.

4. Fladmoe - Lindquist K., Jacque L. L. Control Models in International Service Operations: The Propensity to Franchise. Management Science, Vol 41, No. 7, 1995.

5. Fontaine P. Dešimt Europos pamokų. Vilnius, Gironda, 1998.

6. Held, D.; McGrew, A.; Goldblatt, D.; Perraton, J. Globaliniai pokyčiai: politika, ekonomika ir kultūra. Vilnius: Margi raštai, 2002.

7. Hix, S. The Political System of the European Union. London: MACMILLAN PRESS LTD, 1999.

8. Hofstede, G. Cultural constrains in management theories. Academy of Management Executive, 7, 1992.

9. Juknevičius, S. Skirtingumo dimensijos. Vilnius: Jusida, 2002.

10. Jung, D. I.; Avolio, B. J. Effects of Leadership Style and Followers Cultural Orientation on Performance in Group and Individual Task Conditions. Academy of Management Journal, Vol 42, 1999.

11. Kardelis, K. Mokslinių tyrimų metodologija ir metodai. Kaunas: Technolohija, 1997.

12. Kazlauskas, R. Istorinès antropologijos etiudai. Klaipėda: Menininkų namai, 1993.

13. Kazlauskienè A. Ekonominès migracijos raida Europoje ir Lietuvoje. In: Sociologija: praeitis, dabartis, perspektyvos: mokslinès konferencijos medžiaga. Kaunas: Technologija, 2001.

14. Kolonaitis, R. (red.). Lietuvos integracijos ị Europos Sajungą metraštis. Vilnius: Eugrimas, 2001.

15. Kvedaras, V.; Ruskys, G.; Umbrasas, G. Integration to the EU and its Impact on Lithuanian Economy: Analysis and Quantitative Evaluation. Management of Organizations: Systematic Research (Vytautas Magnus University), No 24, 2002, p. 71-82.

16. Legkauskas, V. Tapatumas ir savimonè: jungtis tarp psichologijos ir sociologijos. Sociologija, Nr. 3-4. Klaipėda, 2000.

17. Lekavičienè, R. Socialinès kompetencijos psichologiniai kriterijai ir vertinimas. Kaunas: VDU leidykla, 2001.

18. Lewis, R. D. Kultūrų sandūra. Vilnius: Alma littera, 1999.

19. Liubinienè, V. Kultūra ir visuomenè. Kaunas: Technologija, 2002.

20. Mayhew, A. Europos Sajungos plètra: derybos su Vidurio ir Rytų Europos šalimis. Vilnius, Eugrimas, 2001.

21. Melnikas, B. Transformacijos. Vilnius: Vaga, 2002.

22. Mitrikas, A. (red.) Vertybės permainų metais. Vilnius: Lietuvos filosofijos ir sociologijos institutas, 1999. 
23. Mockaitis, A. I. Nacionalinių kultūrinių vertybių poveikis vertybinèms nuostatoms: trijų šalių lyginamoji analizè. Daktaro disertacijos santrauka. Vilnius: VU leidykla, 2002.

24. Nachmias, Ch.; Nachmias, D. Research Methods in the Social Sciences. London: St. Martins Press, 1985.

25. Palich, L. E.; Hom, P. W.; Griffeth, R. W. Managing in the International Context: Testing Cultural Generality of Sources of Commitment to Multinational Enterprises. Journal of Management, Vol 21, No 4, 1995.

26. Park, S. H.; Ungson, G. R. The Effect of National Culture, Organizational Complementary, and Economic Motivation on Joint Venture Dissolution. Academy of Management Journal, Vol 40, No 2, 1997.

27. Račiūnaitè, R. Moteris tradicinèje lietuvių kultūroje. Kaunas: VDU leidykla, 2002.

28. ed. Rimkute, J.; Voloschuk, I. Lithuanian Human Development Report 2002-2003. Knowledge, information, technology and human development. Vilnius: Social Policy Unit., 2003.

29. Schultz, T. W. Investavimas i žmones. Vilnius: Eugrimas, 1998.

30. Shane, S.; Venkataraman, S.; MacMillan, I. Cultural Differences in Innovation Championing Strategies. Journal of Management, Vol 21, No 5, 1995.
31. Smith, A. D. Nacionalizmas XX amžiuje. Vilnius: Pradai, 1995.

32. Šalčiuvienè, L.; Auruškevičienè, V. Lietuvos etninių grupių kultūrinių vertybių tyrimas. Organizaciju vadyba: sisteminiai tyrimai, Nr. 24. Kaunas: VDU leidykla, 2002.

33. Šerpetis, K. Kartų sąsajos Lietuvos atgimime. Sociologija, Nr. 1. Klaipeda: KU leidykla, 1997.

34. Šimanskienè, L. Kultūrinių skirtingumų analizè. Tiltai, Nr. 16. Klaipèda: KU leidykla, 2002a.

35. Šimanskienè, L. Organizacinès kultūros formavimas. Klaipèda: KU leidykla, 2002b.

36. Šimanskienè, L.; Venckutè, V.; Župerkienè, E. Kultūrinių skirtingumų ịtaka valdymui. Tiltai, Nr. 13. Klaipèda: KU leidykla, 2003.

37. Tomlinson, J. Globalizacija ir kultūra. Vilnius: Mintis, 2002.

38. Ulčinskaitė, D. (red.). Socialiniai pokyčiai: Lietuva, 1990/1998. Vilnius: Garnelis, 2000.

39. Zakarevičius, P. Vadyba. Genezè. Dabartis. Tendencijos. Kaunas: VDU leidykla, 1998.

40. Žukauskas, P. Kompanijų veiklos internacionalizacijos teorijų vystymasis ir lyginamoji analizè. Organizaciju vadyba: sisteminiai tyrimai, Nr. 14. Kaunas, VDU, 2000. 